\title{
Obstacles to developing sustainable cities: the real estate rigidity trap
}

\author{
V. Kelly Turner $^{1}$
}

\begin{abstract}
Sprawl patterns of urbanization have large environmental consequences, and sustainable alternatives to conventional urban patterns of development have been promoted by a subset of planners, design professionals, and municipalities. These alternatives have not been widely adopted among real estate developers, actors with large influence over urban form and function. Existing explanations for this failure enumerate market and regulatory barriers but do not sufficiently describe the institutional structures that allow conventional approaches to prevail. A failure of real estate developers to adopt alternative forms of development can best be described in terms of a rigidity trap. Specifically, norms of practice within the real estate development industry combine with market and regulatory factors to favor existing practices and limit innovation. Moreover, these institutional factors also buffer the real estate development industry from feedback mechanisms and external signals that might otherwise trigger adaptation. Addressing the environmental consequences of urbanization not only requires novel approaches to urban design, but will also necessitate addressing systemic pathologies in the design implementation process.
\end{abstract}

Key Words: efficiency trap; gilded trap obstacles; private sector; sustainable urban form

\section{INTRODUCTION}

Urban sprawl-low density and fragmented, separate land use, car-centric development (Hayden 2004) - has been a persistent environmental problem in many Western, developed nations and similar patterns of development are emerging globally (Leichenko and Solecki 2005). The "sustainable urbanism" movement in urban planning is a design-oriented response to sprawl style development that is thought to be more environmentally sustainable. Broadly, it argues that compact, mixed-use design, connected by a variety of transportation options and buffered by green space will reduce a variety of environmental challenges associated with sprawl, such as open space consumption and carbon emissions from automobile use (Arendt 1996, Duany et al. 2001, Farr 2008). These design alternatives have gained popularity among some planners, local governments, prospective residents, and a subset of small, niche-market development firms. Increasingly control over the urbanization processes has shifted, however, to large and sometimes national or international real estate development firms (Weiss 1987, Seto et al. 2010), which are party to markets that sustainable alternatives have failed to substantially penetrate (Fuerst and McAllister 2009, Miller et al. 2008). Common explanations for this failure include the high cost of development and prohibitive land-use regulations. Although there are certainly additional upfront costs to "green" development and well chronicled mismatches between zoning and alternative development patterns (Bowman and Thompson 2009, Grant 2009), these explanations may oversimplify the challenge of adopting novel practices against the backdrop of large institutional momentum toward conventional development defined here as the patterns and processes of development that generate sprawl.

Real estate development firms, henceforth developers, can be characterized as de facto land managers of urban socialecological systems in addition to their primary role as private sector companies. Developers have large control over the form and function of urban landscapes directly through construction activities that determine landscape configuration. They also exert indirect influence on ecosystem functioning through urban design that influences user behaviors such as transportation habits, landscaping, and management practices (Cook et al. 2012). Landuse legacies constitute an additional, long-term ecological influence of developers (Grimm et al. 2008). Despite large and long lasting influence over ecological functioning, the management role of the development industry is ultimately de facto because the primary goal of developers has been to purchase, improve, and sell property, not to manage environmental resources. The direct role of the developer in environmental management includes meeting externally imposed regulatory standards, such as storm water drainage requirements or conducting site reviews in ecologically sensitive areas, as opposed to whole system management. In cities, the actors that arguably have the largest control over urban form and function, therefore, have historically had little direct role as environmental stewards.

Drawing from ecological and engineering resilience traditions, urban resilience has been defined as, "the ability of an urban system-and all its constituent socio-ecological and sociotechnical networks across temporal and spatial scales-to maintain or rapidly return to desired functions in the face of disturbance, to adapt to change, and to quickly transform systems that limit current or future adaptive capacity" (Meerow et al. 2016:45). Although the concept of transformation may be over simplified in this definition (Chaffin et al. 2016), two central concepts related to urban resilience are brought to the forefront: an understanding of what constitutes a "desired function" (cf. Meerow and Newell 2016) and "adaptive capacity," or the ability to bounce back from existing and future, unknown disturbances (Eakin et al. 2014). Desired functions in the literature on urban resilience within cities are closely related to land planning and development decisions that determine the composition and configuration of urban lands and the ecosystem services urban systems can provide (Ernstson et al. 2010). Urban land systems are typically associated with large losses in ecosystem services that potentially erode social-ecological resilience (Colding 2007, 
Ahem 2011, Ernstson et al. 2010). Interventions such as incorporating green infrastructure into the urban land matrix or adopting sustainable urbanism design principles may restore some ecosystem services to urban land uses and increase resilience to specific threats (Tzoulas et al. 2007, Andersson et al. 2014, Turner and Galletti 2015), but does not necessarily improve the general adaptive capacity of the social-ecological system. In order to do the latter, new forms of urban land management, such as adaptive governance, may be required to promote widespread and long-term urban resilience (Green et al. 2016). Moreover, the inability to mainstream alternative land practices indicates a lack of adaptive capacity in urban social-ecological systems, at least toward changes that improve ecosystem service delivery.

In this article I examine the role of developers as private sector, de facto land managers in urban social-ecological systems to understand the persistence of conventional sprawl development and the failure of sustainable alternatives to penetrate conventional markets. Specifically, I ask, why have sustainable urban design alternatives failed to achieve widespread adoption sufficient to alter patterns of urban development? Looking to social-ecological systems theories and frameworks on the role of institutions in environmental management may yield new insights into current urbanization trajectories. The study uses an urban resilience framing to glean new insights from urban planning and real estate scholarship. Particularly, I examine the concept of "traps," which posits that maladaptive social-ecological systems persist when institutions and resources mutually reinforce the status quo and inhibit adaptation (Gunderson and Holling 2002, Carpenter and Brock 2008). The application of the traps concept to urban planning and real estate scholarship in this synthesis article suggests that institutional characteristics of the real estate development industry systematically reinforce conventional development and prevent alternatives from entering the market.

\section{THE RISE OF THE REAL ESTATE DEVELOPMENT INDUSTRY, SPRAWL, AND THE FAILURE OF THE SUSTAINABLE URBANISM RESPONSE}

The socio-political forces during the 20th century that contributed to the rise of the real estate development industry and sprawl in the United States have been well chronicled (cf. Jackson 1985, Weiss 1987, Duany et al. 2001, Hayden 2003). Federal housing and home loan policies allowing rapid development increased both the supply and demand for single-family homes. Simultaneously, advances in transportation made plausible development of suburban regions. These trends facilitated the creation of dense subdivisions with ready-made, moderately priced homes on small lots that were developed over short time horizons typified by the Levittown model (Fig. 1). The mid-20th century subdivision model of development tied profit to quick turnover and high volume home sales, with little attention to development quality (cf. Jackson 1985, Weiss 1987, Duany et al. 2001, Hayden 2003).

Weiss (1987) distinguishes between the aforementioned mid-20th century subdivision era and a master planning era beginning in the 1970s and 1980s that placed greater emphasis on development quality. In the master planning era, developers acted like private urban planners, gaining influence over land-use decisions in municipal planning departments and self-imposing restrictive land covenants as quality control on their own developments.
Some of these quality controls such as minimum lot sizes and open space requirements reduced density and the number of lots per development, also reducing the importance of revenue generated from quantity of homes sold. Instead, developers achieved profit targets by increasing home sizes and incorporating luxury amenities that increased the sales price point for each home (Beuschel and Rudel 2009, Rudel et al. 2011). Amenities like parks and other open space land uses attract customers but also drive greenfield development, amenity migration, exurban development, and promote private delivery of public services (Heid 2004, Tilt and Cerveny 2013). Under the master planning model of development, developer control over urban form is hyper evident in luxury developments providing amenities such as parks and man-made lakes that are sometimes inconsistent with regional ecology (Fig. 2). The resulting landscape often occurs at the urban fringe and resembles mid-20th century subdivision sprawl but is larger scale, less dense, and imposes an amenity-driven ecology on the landscape.

Fig. 1. Levittown, Pennsylvania. (https://commons.wikimedia. org/wiki/File:LevittownPA.jpg)

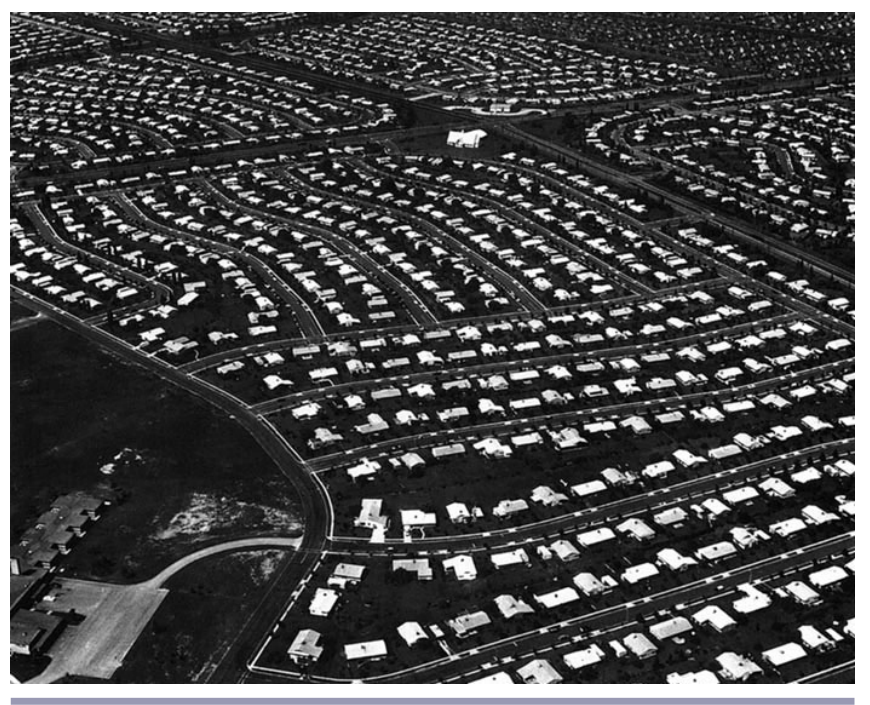

Fig. 2. Rancho Saguarita, Arizona. Example of a large master planned development built at the urban fringe of the desert, featuring private amenities like a water park and man-made lake that have large environmental implications for arid environments (http://www.ranchosahuarita.com/backyard/).

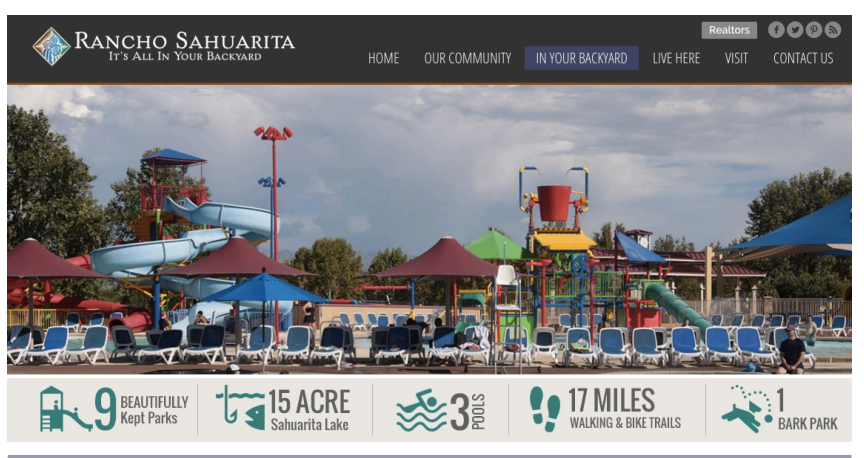


As the power of the real estate developer increased, the influence of the urban planner diminished. This shift of power occurred concomitantly with the rise of "neoliberal" ideology, which argued for a mode of governance that promoted free markets and a noninterventionist state, placing large structural constraints on urban governance writ large (Hackworth 2007). Traditionally, the role of urban plan making was to put forth a vision of what constituted "good" urban form in response to the most pressing needs of society (Talen and Ellis 2002). In the early to mid-1900s, separate use, or Euclidian zoning, emerged as a response to the poor environmental conditions and public health concerns surrounding industrialization and congestion (Pincetl 2010). Focusing on zoning shifted the role of the urban planner from creative plan maker to technocrat, primarily focused on creating and enforcing municipal land-use regulations (Weiss 1987). With developers at the helm, urbanization processes became hyper market-oriented, and the resulting landscape, sprawl, has engendered criticism from the planning community and calls for a return to a "normative" basis of planning (Talen and Ellis 2002). Restoring this role to urban planning today would occur within the context of urban governance that has fundamentally changed since the early 20th century, diminishing the capacity of municipalities to intervene in the market failures of the private sector.

Sustainable urbanism is a reaction against sprawl and includes several design-oriented approaches ranging from the single building or small lot scale to large master planned communities. This definition encompasses disparate design approaches ranging from green buildings to neighborhood-scale conservation subdivisions (or low impact development) and New Urbanism which, applied individually, could lead to substantially different urban form and environmental impact. Although sprawl is typically identified at a municipal or regional scale, the constituent components of urban form that contribute to it are identifiable at multiple scales. At the building scale, large, single-story buildings that encompass whole city blocks contribute to land consumption and undermine walkability (Duany et al. 2001). At the regional scale, "leapfrog" development creates a disjointed landscape that promotes land fragmentation and ignores differences in context and appropriateness of service provisioning along the urban-to-rural transect (Ewing 1994, Duany and Talen 2002). Sustainable urbanism favors urban form that is compact (contiguous), dense (ratio of people or dwellings to land area), mixes land uses, promotes diversity, and incorporates multimodal transit options, passive solar design, and urban greening (Jabareen 2006). Whether or not these self-proclaimed "sustainable" urban design alternatives achieve improvements over conventional sprawl development is a subject of ongoing debate among supporters and critics (Al-Hindi and Till 2001, Ellis 2002, Hostetler and Drake 2009), and beyond the scope of this paper.

There exists a perception among both supporters and critics that sustainable urbanism has not been adopted at rates sufficient to replace conventional development as the dominant form of urbanization (Duany 2013), although evidence to substantiate this perception is elusive. Qualitative accounts and surveys of practitioners attempting to implement sustainable urbanism reveal substantial barriers that inhibit adoption and contextualize, but do not quantify, adoption rates (Grant 2009,
Galuppo and Tu 2010, Bowman et al. 2012, Göçmen 2013, Turner 2014). Quantitative studies of market penetration are likely lacking because few national-scale data sets track sustainable urbanism developments. The official organization for New Urbanism scholars and practitioners, the Congress for the New Urbanism, and various nonprofit organizations maintain listings of New Urbanist projects, but these listings do not differentiate between proposed, planned, and implemented developments and the criteria for project inclusion is not specified (CNU 2016, The Town Paper 2016). One study aggregated listings of New Urbanist projects and, after intensive ground truthing efforts, found approximately 500 site locations in the United States, but did not estimate market penetration (Trudeau and Malloy 2011). Another set of national-scale data sets available to assess market penetration of alternative development are produced by third party rating systems for building design standard (e.g., Leadership in Energy Efficient Design - LEED, Energy Star) and neighborhood scale design (LEED for Neighborhood Development - LEED-ND). Third party rating systems are an imperfect measure because not all sustainable urbanism developments seek certification and many certified sites only adopt a limited subset of design principles (Garde 2009). Studies carried out on the adoption of green building standards in commercial buildings suggest limited market penetration. For example, a survey of large real estate developers revealed that none had adopted green building standards in more than $20 \%$ of their projects and most had only adopted standards in about $2 \%$ (Miller et al. 2008). Although adoption of green building design standards is rising in the new construction market according to one study (up to $30 \%$ of new development was green building in 2010 over $5 \%$ in 2000), the majority of these buildings are municipally owned with only $30 \%$ of green buildings developed for private sector customers (Wiley et al. 2010, Kok et al. 2012). Adoption of green building standards varies considerably by state and municipality; according to one study, even states with high total volume and percentage of new green building construction, like California and Oregon, had captured $5 \%$ or less of the commercial building market between 2000 and 2010 (Choi and Miller 2011). Only 181 and 231 sites are listed as LEED-ND projects in the United States and internationally, respectively, and, like other databases, planned and built projects are not differentiated (US GBC 2016a). Although none of these data sets is perfect or complete, it is safe to say that market penetration of sustainable urbanism is nominal given that databases estimate the cumulative number of planned and built green buildings and neighborhoods in the United States on the order of thousands and hundreds, respectively, and the number of annual new residential housing completions on the order of hundreds of thousands (U.S. Department of Housing and Urban Development 2016, US GBC 2016a,b).

\section{THEORIES TO EXPLAIN THE FAILURE OF THE SUSTAINABLE URBAN RESPONSE: MARKET, REGULATION, AND POLITICAL ECONOMY}

Several explanations have been advanced to explain why widespread adoption of sustainable urbanism has yet to occur. These fall broadly into market, regulatory, and political economy explanatory categories. Although each offers some insights into the challenges of implementing alternative development, none provides a complete understanding of the institutional structures that create these conditions. 
Market-based explanations contend that developers have determined that sustainable development is cost prohibitive and often prescribe novel forms of market analysis to counter developer perceptions. For instance, while conceding that there are increased upfront costs associated with green materials and technologies, low impact development practices, permitting and certification fees, and protracted development time lines (Carter 2009, Bowman and Thompson 2009), several studies demonstrate that green alternatives also capture a market premium in sales (Pejchar et al. 2007, Choi 2009, Eichholtz et al. 2010, Talen 2010). This market premium should, in theory, be attractive to the real estate development industry; however, evidence suggests that developers may underestimate public demand (Bowman and Thompson 2009, Galuppo and Tu 2010). Indeed, there is a general perception among private sector actors that sustainable urbanism is risky, which materializes as actual increased risk to developers because investors demand a quicker and higher rate of return for these projects (Gyourko and Rybczynski 2000). Perception of risk may be rooted in the real estate industry standard of precedentbased market analysis through which investors examine five years of market performance of comparable development types in similar markets to make financing decisions. Many sustainable urbanism developments lack such comparable developments anywhere, let alone in similar markets, and sufficient data to complete market analysis may be unavailable. Alternative market analysis, such as contingent valuation methods that assess homebuyer willingness-to-pay for hypothetical sustainable urbanism developments have less traction within the risk-adverse real estate industry because they are unproven prospects (Goering 2009, Runde and Thoyre 2010). Furthermore, developers who try sustainable development do so based on word-of-mouth from trusted colleagues and specifically distrust academic market analysis (Kingsley 2008). In sum, sparse and often hypothetical evidence about long-term profits or consumer preferences is insufficient to convince developers and investors that sustainable urbanism is more profitable than conventional development in the long run because alternative market analysis is incongruent with real estate industrial norms of operation.

Regulatory explanations for the poor level of uptake of sustainable urbanism point to the lack of land use and other legal mechanisms compelling developers to build them. In fact, sustainable urbanism contends that land-use regulations via zoning rules drive sprawl and render compact, mixed-use alternatives illegal by separating land uses and specifying minimum lot sizes, building set backs from the street, and street widths (Duany et al. 2001). This has led to calls for special ordinances, such as Traditional Neighborhood Development and Low Impact Development ordinances, to make legal New Urbanist and Conservation Subdivision developments, respectively (Arendt 1996, Duany et al. 2001). Emerging evidence suggests mixed success of such ordinances because of variability in the quality of regulations, some of which permit relatively conventional developments to pass as sustainable alternatives (Beuschel and Rudel 2009, Langlois 2010, Wald and Hostetler 2010, Göçmen 2013). Interestingly, recent surveys found that developers do not perceive land-use regulations or building codes as having much of an impact on the implementation of sustainable alternatives, although they do view the planning agencies that enforce them as inflexible (Bowman and Thompson 2009, Bowman et al. 2012, Galuppo and Tu 2010). In addition to landuse regulations, some municipalities offer incentives, such as grants or tax breaks to developers; however, these incentives tend to be relatively small compared with the high cost of development and do not offset additional costs or risks associated with sustainable urbanism development (Kingsley 2008, Choi 2009). The inefficiency of subsidies for green development was demonstrated in one study that found that $88 \%$ of developers receiving subsidies would have developed in exactly the same way without them (Cowan 2012). A fundamental problem with both special ordinances and one-time financial investments is that they do little to reduce land holding costs associated with owning and improving a property: taxes, interest on loans, insurance, utilities, and maintenance. Some have suggested that a mix of tools that address different stages of the development process, such as expedited plan reviews or tax increment financing, may be more appropriate incentives to compel developers to try sustainable urbanism (Arendt 2004, Choi 2009). Regulatory explanations that suggest one time interventions or subsidies for overcoming legal barriers to alternative development do not sufficiently address the barriers to sustainable development that are spread across multiple stages of the development process. Nor do they offer financial incentive solutions commensurate with the cost of real estate development.

A subject of ongoing debate remains whether regulatory "carrots, " e.g., incentives, or "sticks," e.g., penalties, would be more effective in promoting sustainable urbanism (Cowan 2012). It is generally agreed, however, that voluntary, third-party certification systems like LEED-ND have only modest utility in promoting wider spread adoption of green practices. Although certification systems ostensibly generate publicity or have marketing advantages for developers, evidence is scarce (Garde 2009, Falkenbach et al. 2010). Moreover, certification systems are tied to design as opposed to performance, so it is difficult to know if sustainable design principles are working in practice (Retzlaff 2008, Garde 2009). Perhaps most problematic is the tendency for developers to "satisfice," seeking certification for projects that require only modest adjustments to their existing development plans to qualify for certification or accruing many points for criteria with the least potential environmental benefits while not pursuing criteria with large environmental benefit that would have required big changes in design or implementation (Kingsley 2008, Garde 2009, Mohamed 2009). Moreover, incentives and penalties create problems of nonimplementation free riding and nonadaptive implementation, respectively, suggesting that a mix of both "carrots and sticks" may be necessary (Markus and Savini 2016).

Previous studies on market and regulatory explanations list barriers to alternative design implementation that dissuade developers from adopting it and offer interventions to overcome those barriers. Even when interventions are implemented they fall short of promoting high adoption rates because they do not fully address the institutional interactions that systematically reinforce conventional sprawl development practices. A third explanatory framework, political ecology, contends the interactions between market, regulatory, and socio-political factors work to reinforce the status quo. Political ecology uses in-depth case studies of the 
implementation process to reveal the institutional interactions that inhibit sustainable urbanism. These studies focus on broadscale institutional forces including, for instance, the politics of smart growth and energy independence that are reinforced through local regulations, and subject to "boom-and-bust" cycles of the real estate industry (Rybczynski 2007, Hurley 2012). Political ecology studies are few in number and largely based on individual cases and, therefore, limited in their capacity to produce general insights about institutional interactions that hinder and help promote sustainable urbanism.

Finally, within the real estate industry, practitioners have characterized the failure of sustainable urbanism to supplant conventional development as a "viscous circle of blame" (Cadman 2000, unpublished manuscript). In this blame circle, (1) home builders can build sustainable buildings but developers do not commission them; (2) developers would commission them but investors will not finance them; (3) financial institutions would finance them but market demand is not proven; and (4) end users, e.g., homeowners, would occupy them but home builders introduce few options to the market. The vicious circle of blame suggests that development patterns will continue somewhat path dependently toward sprawl because the institutions responsible for development have become locked in to a particular mode of operation. If the circle of blame explanation is true, it suggests that alternative development may have had limited uptake because the real estate development industry is caught in a rigidity trap, unable to adapt to new ideas about sustainable design.

\section{TRAPS IN LAND MANAGEMENT AND THE PRIVATE SECTOR}

Resilience scholarship has adopted the concept of traps to explain the emergence and persistence of unsustainable management practices (Gunderson and Holling 2002, Carpenter and Brock 2008, Boonstra and de Boer 2014, Enqvist et al. 2016). Traps describe different pathological states in social-ecological systems that decrease the ability to adapt in response to change. Traps describe systems that are persistent, but maladaptive having become locked-in a particular way of functioning. Two main types of traps, poverty and rigidity, have been deployed in the resilience literature and though both describe systems that are unable to change, the characteristics of social-ecological systems that lead to each are distinct (Carpenter and Brock 2008; Table 1).

Table 1. Characteristics of poverty and rigidity traps (adapted from Carpenter and Brock 2008).

\begin{tabular}{llcc}
\hline \hline Characteristic & Description & Poverty & Rigidity \\
& & Trap & Trap \\
\hline Heterogeneity & Diversity of connections & High & Low \\
Connectivity & Strength of ties & Low & High \\
Exploration & Ability to explore new strategies & High & Low \\
Focus & Resources directed to specific & Low & High \\
& strategy & Low & High \\
\hline Stress & Effort expended to adapt & & \\
\hline
\end{tabular}

Poverty traps, a term first used by economists (Carter and Barrett 2006, Dasgupta 1997, Barrett et al. 2011), describe a situation in which individual agency to overcome poverty is inhibited because of social-ecological dynamics, e.g., shocks or chronic stress, that reinforce it (Gunderson and Holling 2002, Carpenter and Brock 2008, Cinner 2011). Poverty traps, occur when diverse systems have the capacity to explore new strategies, but do not have sufficient focus of resources required to adapt. Poverty traps have been used to describe how individuals in resource dependent societies choose livelihood strategies that yield low and short-term gains in order to protect existing assets (Cinner 2011). Although most of the literature has focused on financial or social capital, some have suggested that systems may also be deficient in resources such as political will or public support as well (Moore and Westley 2011).

Rigidity traps, in contrast, occur in systems that have abundant resources, but become resistant to change, usually through institutional arrangements that reinforce the status quo. In a rigidity trap, diversity and the ability to explore new strategies is reduced in favor of high connectivity and focus on specific strategies. With resources and connections bound up in a specific path, adaptation places high stress on the system because it requires high effort to institute changes. The rigidity trap concept has been used to describe natural resource or land management systems in which social or ecological feedback mechanisms are unable to trigger a change in management under conditions of stress. At the root of many of these potentially maladapted land management systems are command-and-control policies intended to reduce uncertainty about the ecological functioning of natural resources by reducing ecological diversity and variability that lead, perversely, to an increase in variability and surprise. For example, forest fire suppression in the American Southwest is a land management system that was designed to reduce the threat of wildfire by mitigating fires; however, it neglected the ecological function of fires in forest systems leading to the accumulation of fire-fuelling biomass and catastrophic fires. This management system qualifies as a rigidity trap because it persisted, despite feedback mechanisms that warned against it, such as the knowledge that such practices contributed to an increase in burn intensity and frequency, unsustainable fire suppression costs, and public risk (Butler and Goldstein 2010). Some dimensions of land management systems caught in a rigidity trap may exhibit immobility, e.g., fire suppression management, while other dimensions may exhibit large fluctuations, e.g., increase fire conflagration size, intensity, and suppression cost (Carpenter and Bock 2008). Even large, negative social and ecological consequences of existing land management systems are insufficient to trigger a management change in a rigidity trap because, often, those in a position of power stand to accumulate benefits at least in the short run (Gunderson and Holling 2002, Allison and Hobbs 2004, Carpenter and Bock 2008). Indeed, increased vulnerability to external disturbances is the primary negative outcome of traps. In the real estate industry, continued sprawl development may result in urban socialecological systems that are vulnerable to external disturbances such as a rise in the cost of fuel, which residents depend on in auto-dominated landscapes, or the loss of tax revenue due to migration, e.g., movement from the northern "Rustbelt" to southern "Sunbelt" region of the U.S., which leads to aging infrastructure and reduced property values. It is important to note that developers are somewhat buffered from such shocks because they usually occur after sales transactions have occurred. 
Two additional types of social traps, "efficiency traps" and "gilded" traps, are helpful in understanding the role of private sector actors in creating trap situations because they describe processes through which the primary drivers are market viability and resource value, respectively. Scheffer and Westley (2007) describe an efficiency trap, which exists in systems that respond to stress by focusing inward and by increasing efficiency locally but rejecting alternative modes of operation. As such, once optimal systems become suboptimal as conditions change over time. Efficiency traps help explain the failure of large, private sector firms to innovate, even when existing modes of operation put them at a competitive disadvantage in the broader business landscape because of a tension between exploratory and exploitative processes. Exploratory processes that potentially lead to innovation occur in small, innovative firms, while exploitative processes that are capable of bringing new ideas to market viably require increased efficiency and precision. Over time, exploration may be viewed as wasteful and firms may become homogeneous, vulnerable to "group think," and generally resistant to new ideas even when facing marginal returns for increased efficiency. Like rigidity traps, feedback mechanisms fail to trigger change in efficiency traps because a highly connected, homogeneous group benefits in the short run from refining existing modes of operation.

Steneck et al. (2011) introduce the concept of gilded traps to explain situations in which the high value of resources explains the persistence of unsustainable practices. In gilded traps, economic value is prioritized over social and ecological risk. The authors use the example of Maine Fisheries in which the high value of lobster has led to actions that reduce biological diversity in order to maximize productivity while reducing the overall resilience of the system. The authors hypothesize that gilded traps will become increasingly prevalent in systems that do not take steps to protect the functional diversity of ecosystems. The example provided by Steneck and colleagues focuses on the functional diversity of a natural resource system; however, functional diversity is also critical to the resilience of many human-dominated land systems (Díaz et al. 2007, 2011). Urban land systems typically reduce functional diversity, depending on ecological context and scale of analysis (Grimm et al. 2008, Groffman et al. 2014, Polsky et al. 2014). Yet the linkages between human well-being and ecosystem functioning in urban land systems may often be less direct or apparent than in natural resource systems linked to provisioning services (e.g., agriculture, aquaculture, forestry) because urban stakeholder livelihoods and well-being are usually bound to the condition of resources that provide cultural (e.g., recreation, tourism, aesthetics) and regulating (e.g., storm water, climate) services.

\section{THE REAL ESTATE DEVELOPMENT INDUSTRY RIGIDITY TRAP}

The real estate development industry exhibits characteristics of a system in a rigidity trap, as indicated by the circle of blame. What the circle of blame fails to account for, and the rigidity trap framework helps elucidate, are the specific institutional structures that cause this lock in. Table 2 uses the rigidity trap framework to unpack the attributes of the real estate industry that contribute to the inability to adapt in ways that incorporate sustainable design alternatives.
Table 2. Evidence of a rigidity trap in the real estate industry.

\begin{tabular}{lccl}
\hline \hline $\begin{array}{l}\text { Trap } \\
\text { Characteristic }\end{array}$ & $\begin{array}{c}\text { Rigidity } \\
\text { Trap }\end{array}$ & $\begin{array}{c}\text { Real } \\
\text { Estate }\end{array}$ & Industry Characteristics \\
\hline Heterogeneity & Low & Low & $\begin{array}{l}\text { Economies of scale: small } \\
\text { number of large firms }\end{array}$ \\
Connectivity & High & High & $\begin{array}{l}\text { Vertical integration and cliques } \\
\text { Focus }\end{array}$ \\
High & $\begin{array}{l}\text { High } \\
\text { Market segmentation } \\
\text { Higs }\end{array}$ & High & $\begin{array}{l}\text { New design requires institutional } \\
\text { reorganization }\end{array}$ \\
Exploration & Low & Low & Risk averse \\
\hline
\end{tabular}

The real estate industry is homogeneous, dominated by a small number of large, well-established national and international firms (Coiacetto 2006, Seto et al. 2010). This dominance is due, in part, to the increased complexity of projects under the master planned development model; larger firms have greater capacity to handle complexity because of expertize and management ability (Bradshaw 2011). Investors and lending institutions reinforce this trend by favoring highly capitalized firms with efficient economies of scale and a track record of success; this makes it difficult for new and potentially innovative firms to gain entry into the industry (Coiacetto 2006). Sustainable urbanism is usually viewed as a more complex project type than conventional development and, although large firms have the greatest capacity to implement these complex development types, they have failed to do so, perhaps, because of lack of diversity among large firms.

The real estate development industry can be characterized as highly connected trending toward increased vertical integration with individual firms controlling virtually all aspects of the development process (Weiss 1987). Developers drive this trend by controlling contracted services such as design, home construction, and material supply, increasingly integrating these services into firm business models and by limiting contracts to preferred firms (Coiacetto 2007). Historically, the real estate industry had been characterized as a project-based, loosely coupled system in which various actors, e.g., developers, homebuilders, designers, and engineers, form coalitions to complete individual projects, with few repeated interactions among firms (Vrijhoef 2011). These characteristics were thought to be inefficient and restrictive for innovation, knowledge sharing, and learning leading to calls within the industry for increased integration and repetition of interaction among firms (Vrijhoef 2011). This organizational shift has resulted in discrete clusters of firms that tend to be hired by clients that require repetition of similar project types (Brady et al. 2005). These clusters of partnerships may become more efficient through in-network learning, but not necessarily more innovative if interactions are restricted to "cliques" in the network, organized around single project types. One hypothesis for the paucity of uptake of sustainable urbanism may be the lack of knowledge sharing brokers between vertically integrated firms and project type "cliques." In sum, the real estate industry has shifted away from the polycentric network structures thought to support innovation and learning in many complex social-ecological systems (Ostrom 2010). 
Agglomeration trends in the real estate industry are reinforced by market segmentation and the tendency of firms to specialize, or focus, in particular "product" types (e.g., lifestyle, life stage, price point), geographies (e.g., urban, suburban), and sectors (e.g., commercial, residential; Coiacetto 2007). Lenders, investors, and, most recently, real estate investment trusts (REITs) reinforce this tendency by focusing on single market segments and standard "products" to facilitate trading on Wall Street (Gyourko and Rybczynski 2000). REITs are real estate investment securities that are bought and sold like a stock and are attractive to investors because, unlike brick-and-mortar development, they are liquid assets. Additionally, REITs may qualify for special tax breaks and usually yield high dividends. REITs also focus almost exclusively on a particular market segment (Pinedo et al. 2016). Unconventional "products," like sustainable urbanism developments that cross market segments, are, therefore, more difficult to finance, particularly when they call for features such as large conservation areas or mixed-income development that require complex financing arrangement (Leinberger 2001, Talen 2013).

The combined effect of economies of scale, vertical integration, and market segmentation reduce the adoption of sustainable urbanism because many of the proposed design ideas require system-wide changes to standard practices in the real estate industry and individual firm structure to be financially viable. In short, implementing sustainable urbanism designs places stress on the real estate development industry. Stress may be particularly disruptive for large firms that report difficulty adopting new design standards without completely overhauling supply chains or business models (Rudel et al. 2011). Moreover, the ability to adopt new ways of developing decreases over time as firms become more homogenous, connected, and focused; this restricts the developers' ability to make changes as a project progresses or in subsequent projects (Bradshaw 2011). In sum, adopting alternative designs creates stress because it requires major institutional reorganization to finance and deliver those products to market.

These stressors, compounded by culture of market conservatism, make the real estate industry particularly cautious of exploration. New ideas are only adopted if they have proven ability to capture market premiums (Krause and Bitter 2012). Investors cultivate culture of market conservatism by funding only those projects that meet a narrow definition of "proven ability": market premiums evidenced through a five-year, precedent-based market analysis (Carter 2009). Yet many of the benefits of sustainable urbanism developments are accrued over long-term time horizons, e.g., energy savings, or not directly captured in market valuation, e.g., habitat preservation, leading developers and financers to apply heavy discount rates to these potential returns on investment in sustainable urbanism (Gyourko and Rybczynski 2000, Mohamed 2006).

The real estate development industry also bears some of the hallmarks of the efficiency trap: increasing the efficiency of the status quo in response to internal and external system changes. For example, evidence suggests that firms specializing in sustainable urbanism vertically integrate at higher rates than conventional firms, which provides a competitive advantage in terms of increased efficiency but also hinders flexibility during project implementation (Bradshaw 2011). Conventional development firms are also increasing efficiency, especially in response to changing market conditions. For instance, the Great Recession and housing market crash in 2008, ushered in a series of changes in real estate and, as a result, the industry trended toward increased rigidity and efficiency. A large number of firms went bankrupt during the housing market crash and mostly larger firms survived, reinforcing homogeneity in the industry in which a small number of large firms dominate the industry. Financial institutions may be responding by tightening real estate loan standards, increasing the amount of capital, track record of success, and legal documentation required of development firms, further favoring large institutions, emphasizing asset funds like REITs, and restricting investment to a smaller number of development firms (Sharpe 2011, Bergsman 2012). One survey of construction industry professionals found that the most popular responses to the recession were the adoption of technologies to design prefabricated and modular materials and blending of design, development, and construction "disciplines" (Aydukovic 2013, https://blogs.ubalt.edu/real-estate/2013/02/25/the-criticalpath/). REITs, modular materials, and integrating "disciplines," are examples of incremental innovations, or recombination of existing ideas, and serve to reinforce existing institutional trajectories as opposed to more transformative innovations that would challenge rules governing the system (Biggs et al. 2010, Moore and Westley 2011). These responses are examples of innovations that are initially advantageous because they increase efficiency in the short run, but exclude alternatives, like sustainable urbanism, and may reduce resilience over longer time periods (Scheffer and Westley 2007, Carpenter and Brock 2008, Enqvist et al. 2016). Although not yet empirically tested, if these observations hold, the real estate industry is on track to reinforce institutional structures such as homogenization, connectivity, and focus that restrict experimentation, create stress when confronting change, and generally restrict adaptive capacity.

Finally, the real estate industry also resembles a gilded trap (Steneck et al. 2011), in which the monetary value of a natural resource as a provisioning service is sufficiently high to offset concerns about long-term social and ecological risk. In the case of real estate development, the natural resources in question, usually land, but also water bodies and other natural "amenities," has high value to a developer once it has been "improved" by building on it. Some of the ecological risks of development practices such as degraded water resources or habitat fragmentation could, potentially, degrade land value; however, in conventional development, these costs usually occur long after homes have been sold and the costs are redistributed to homeowners and municipalities.

\section{"ROAD SIGNS": PROXIMATE CAUSES OF THE TRAP}

Understanding the causal mechanisms of traps is critical for identifying effective solutions. Traps have been characterized as a process, shaped by historic conditions and events and reinforced by shorter term signals (Coss and Guyer 1980, Costanza 1987, Boonstra and de Boer 2014). Examining social-ecological systems over mid- to long-term time frames (decades to centuries) reveals "antecedent conditions" that define the range of available management options, "critical junctures" in which management options are selected, formation and reproduction of institutions that allow the trap to persist, and the reactions to trap situations (Boonstra and de Boer 2014). Such analysis resembles a historic 
or political ecology approach, and, with regard to the real estate industry and urban development, has been sufficiently addressed by a variety of authors (Jackson 1985, Weiss 1987, Duany et al. 2001, Hayden 2003, Hackworth 2007). Costanza (1987) likens proximate causes of traps to misdirection in the "road signs," i.e., the incentives that directly influence decision making, creating a gap between short-term, individual behavior and long-term, global best interest. The "road signs" in the real estate industry that direct decisions away from adopting sustainable urbanism are those that externalize current and discount future environmental costs of development.

Negative environmental externalities are a type of market failure in which the societal cost of environmental change is not reflected in transaction costs. Conventional real estate development processes externalize the environmental costs associated with sprawl patterns of development, limiting the extent to which these costs will influence developer decisions to adopt sustainable alternatives. Scholars have noted that sprawl style development requires social service, e.g., fire or police, and infrastructure expansions and maintenance, the costs of which often fall on municipalities (Duany et al. 2001). Similarly, development creates environmental costs, many of which are not reflected in real estate transaction costs. For example, developers are required to provide and pay for the construction of infrastructure to detain storm water to prevent flooding; however, these regulations have not prevented land development in many regions from increasing flooding, sewage overflows (in combined systems), impairing aquatic ecosystems, and costing municipalities in the U.S. billions of dollars to manage (Wise 2008). Storm water management costs are largely external to the transaction costs of development, which provides little incentive for developers to adopt more sustainable alternatives that could reduce storm water runoff in the first place. Indeed, ecosystem services and other public benefits are not necessarily captured in real estate transaction value. A large number of studies have attempted to illustrate how sustainable alternative land development patterns deliver ecosystem services and public benefits and determine if these benefits are captured in housing markets. Although the relationship between open space and home value has been well established (Lutzenhiser and Netusil 2001, Geoghegan 2002, Song and Knaap 2004, Kopits et al. 2007, Pejchar et al. 2007), few ecosystem services are captured in real estate exchange value. For instance, proximity to natural aquatic ecosystems and urban forests does not necessarily increase home value (Oleyar et al. 2008, Kaza and BenDor 2013). Additionally, many have suggested that car-centric development restricts walkability and has links to obesity, which has public health costs (e.g., Cervero and Radisch 1996, Ewing et al. 2008). Empirical studies on the link between more compact and walkable forms of development and property values have returned mixed results (Bowes and Ihlanfeldt 2001, Song and Knaap 2004, Hess and Almeida 2007, Atkinson-Palombo 2010, Duncan 2011). Because these costs to conventional development are external to real estate development transactions, they do not provide sufficient feedback to provoke changes like adopting alternative development.

Social traps can be caused by a time delay between positive incentives today and negative ones in the future (Costanza 1987), such as the tendency to "discount" future environmental costs. Developers have bounded tenure, meaning they demarcate landuse and management practices for land systems in which they have only short-term profit stakes, often entrenching land management practices that degrade the environment in the long run. Bounded tenure reinforces the rigidity trap because developers have little incentive to adopt sustainable urban development practices that would provide environmental benefits or avoid environmental costs beyond the time horizon of financial interest. Although developers may provide amenities and services such as parks and common space, the long-term maintenance costs often fall on municipalities if public or homeowners if private. For instance, the conventional master planning model of development ostensibly protects property values over the long run via aesthetic standards (covenants, codes, and restrictions) and private management (homeowner associations [HOAs]), which distributes the cost of funding the maintenance of private amenities to homeowners via dues. One HOA for a subdivision near Columbus, Ohio voted to increase dues to engage in environmental monitoring and management of a lake resource when nutrient runoff from yard fertilization and erosion from lake front development and recreational use degraded water quality and created harmful algae blooms, threatening the lake amenity and property values (Higgins 2015). On a longer time scale, a survey of Australian developers found that nearly $85 \%$ expressed little incentive to address climate change because the environmental impacts and costs occur beyond the time line of development (Shearer et al. 2013). The authors conclude that the issue of, "short term commitment versus long-term consequences is fundamental to the issue of sustainability in property development" (Shearer et al. 2013:45).

\section{BUILDING ADAPTIVE CAPACITY FOR SUSTAINABLE URBANISM}

The rigidity trap framing suggests that building sustainable cities will also require building greater adaptive capacity into the real estate development process. This can be done by correcting the "road signs" that direct developers toward the status quo sprawl style development and replacing them with signals that encourage experimentation with sustainable alternatives. Specifically, greater adaptive capacity can be fostered by addressing the socialecological system characteristics - heterogeneity, connectivity, focus, stress, and exploration - that are symptomatic of a system caught in a rigidity trap and the related issues of externalities and discounting that reinforce it. These solutions would likely involve a mix of private sector and government interventions.

Greater adaptive capacity could be promoted by increasing heterogeneity among real estate development firms by directing public sector financial incentives to small, innovative firms already experimenting with sustainable urbanism at small scales. These public sector investments could include financing mechanisms like property tax abatement and tax increment financing that reduce land holding costs over the protracted time lines required for sustainable urbanism projects until property sales may commence to pay for development. Experimentation could be encouraging through partnerships between small innovative and large mainstream firms. Such partnerships would combine capacity for innovation and capacity to secure financial sector investments and manage complex projects. Shifting to a more polycentric approach - organizations have independent but partially overlapping responsibilities (Ostrom 2010) - to urban development, as opposed to the current structure of highly connected, vertically integrated, and specialized cliques, could 
encourage learning and experimentation. Additionally, a collaborative, polycentric approach to development could be leveraged to encourage project complexity while retaining each firm's ability to focus resources on particular areas of specialization. Several authors have suggested methods for streamlining bureaucratic processes for complex projects, e.g., mixed use, such as allowing more flexible "sketch maps" to be sufficient for development approvals (Arendt 2004). Support for complex project types could also be bolstered in the financial sector through interventions designed to encourage trading of mixed use REITs on the stock market and by leveraging sales tax from commercial and retail use in mixed use development to finance other land uses and environmental amenities (Bradshaw 2011, Turner 2016). The emphasis on supply chain efficiency that causes experimentation to create financial stress could be addressed through flexible supply chain strategies such as multifirm supply chain consortiums that allow companies to integrate new products while mitigating risk (Simatupang and Sridharan 2002). Finally, creative financing schemes can be used to internalize externalities and address discounting by lengthening the time line for which developers have a stake in a project. For example, "pay for performance" bonds, also known as social impact bonds, tie earnings to project performance, usually a desired social outcome. Although developed to address social issues such as homelessness, a new application as an environmental impact bond will tie green infrastructure development to storm water management performance in Washington D.C. (Valderrama 2016). Similar financing schemes have been suggested for sustainable urban development, but have yet to be deployed (Church 2014, White 2014). These are just a few examples of how public and private sector interventions can increase adaptive capacity in the real estate industry by addressing the proximate causes of rigidity in the current system.

\section{CONCLUSIONS}

The purpose of this paper was to gain new insights from planning and real estate literature about the persistence of sprawl and the failure of sustainable urbanism to penetrate the market using the concept of traps. Sprawl persists because policies and resources are tied to development processes that facilitate it that were shaped by well-known, broad scale socioeconomic forces (cf. Jackson 1985, Weiss 1987, Duany et al. 2001, Hayden 2003) and are reinforced by the particularities of land development and finance today. Specific trends in the real estate industry such as increased economies of scale, vertical integration, and market segmentation reduce financial risk, but also decrease the propensity to adopt alternative design practices. These institutional characteristics, homogeneity, connectivity, and focus, are indicative of a system in a rigidity trap with low capacity for exploration of alternatives. Current trends in real estate appear to show that entrenchment, as opposed to experimentation, has been the response to stress, an organizational response observed in the private sector called an efficiency trap (Moore and Westley 2011). Moreover, externalities due to failure to account for nonmarket costs and benefits and "bounded tenure," provides little incentive for real estate firms to adopt alternative practices because they are buffered from many negative feedbacks.

Finding solutions to the environmental challenges of global urbanization can benefit from leveraging existing socialecological frameworks to understand new problem domains.
Here, the concept of traps elucidates interdependencies in private sector dynamics between real estate developers, financial institutions, contracted services, e.g., homebuilders, and customers that create path dependency in land development that reinforces sprawl. It also highlights a set of solutions that could increase adaptive capacity within the real estate development industry through public and private interventions. Widespread adoption of sustainable alternatives will only be likely if these interdependencies, especially those related to real estate finance, are addressed. Novel financial instruments and mechanisms for mitigating risk may need to be developed by establishing stronger linkages between the physical (planning, development, construction) and monetary (finance and banking) stakeholder groups (Rohde and Lutzkendorf 2009). Additionally, creative solutions to the structures that reinforce rigidity, i.e., homogeneity, connectivity, and focus, need to be addressed to reduce stress and increase exploration. Greater engagement with private sector actors is likely a first step in identifying targeted solutions that increase adaptive capacity within the real estate development industry to promote urban sustainability. Unsustainable patterns of urban development are unlikely to change if the institutional mechanisms that drive real estate development remain the same.

Responses to this article can be read online at: http://www.ecologyandsociety.org/issues/responses. $\mathrm{php} / 9166$

\section{LITERATURE CITED}

Ahem, J. 2011. From fail-safe to safe-to-fail: sustainability and resilience in the new urban world. Landscape and Urban Planning 100(4):341-343. http://dx.doi.org/10.1016/j.landurbplan.2011.02.021

Al-Hindi, K. F., and K. E. Till. 2001. (Re)placing the new urbanism debates: toward an interdisciplinary research agenda. Urban Geography 22(3):189-201. http://dx.doi.org/10.2747/0272$-3638.22 .3 .189$

Allison, H. E., and R. J. Hobbs. 2004. Resilience, adaptive capacity, and the "lock-in trap" of the Western Australian agricultural region. Ecology and Society 9(1):3. http://dx.doi. org/10.5751/es-00641-090103

Andersson, E., S. Barthel, S. Borgström, J. Colding, T. Elmqvist, C. Folke, and Å Gren. 2014. Reconnecting cities to the biosphere: stewardship of green infrastructure and urban ecosystem services. Ambio 43(4):445-453. http://dx.doi.org/10.1007/s13280-014-0506y

Arendt, R. 1996. Conservation design for subdivisions: a practical guide to creating open space networks. Island Press, Washington, D.C., USA.

Arendt, R. 2004. Linked landscapes: creating greenway corridors through conservation subdivision design strategies in the northeastern and central United States. Landscape and Urban Planning 68(2-3):241-269. http://dx.doi.org/10.1016/s0169-2046 (03)00157-9 
Atkinson-Palombo, C. 2010. Comparing the capitalisation benefits of light-rail transit and overlay zoning for single-family house and condos by neighbourhood type in metropolitan Phoenix, Arizona. Urban Studies 47(11):2409-2426. http://dx.doi. org/10.1177/0042098009357963

Barrett, C. B., A. J. Travis, and P. Dasgupta. 2011. On biodiversity conservation and poverty traps. Proceedings of the National Academy of Sciences 108(34):13907-13912. http://dx.doi. org/10.1073/pnas.1011521108

Bergsman, S. 2012. Side effects: in the recession's aftermath, investors and investment managers recalibrate how to deal with real estate and one another. Institutional Real Estate Americas 24 (9).

Beuschel, V., and T. K. Rudel. 2009. Can real estate developers be "green"?: Sprawl, environmental rhetoric, and land use planning in a New Jersey community. Society and Natural Resources 23:97-110. http://dx.doi.org/10.1080/08941920802013981

Biggs, R., F. R. Westley, and S. R. Carpenter. 2010. Navigating the back loop: fostering social innovation and transformation in ecosystem management. Ecology and Society 15(2):9. http://dx. doi.org/10.5751/es-03411-150209

Boonstra, W. J., and F. W. de Boer. 2014. The historical dynamics of social-ecological traps. Ambio 43:260-274. http://dx.doi. org/10.1007/s13280-013-0419-1

Bowes, D. R., and K. R. Ihlanfeldt. 2001. Identifying the impacts of rail transit stations on residential property values. Journal of Urban Economics 50(1):1-25. http://dx.doi.org/10.1006/juec.2001.2214

Bowman, T., and J. Thompson. 2009. Barriers to implementation of low-impact and conservation subdivision design: developer perceptions and resident demand. Landscape and Urban Planning 92:96-105. http://dx.doi.org/10.1016/j.landurbplan.2009.03.002

Bowman, T., J. Thompson, and J. Tyndall. 2012. Resident, developer, and city staff perceptions of LID and CSD subdivision design approaches. Landscape and Urban Planning 107(1):43-54. http://dx.doi.org/10.1016/j.landurbplan.2012.04.011

Bradshaw, W. B. 2011. Creative construction: the capacity for environmental innovation in real estate development firms. Journal of sustainable Real Estate 3(1):274-311.

Brady, T., A. Davies, and D. Gann. 2005. Can integrated solutions business models work in construction? Building Research and Information 33(6):571-579. http://dx.doi.org/10.1080/09613210500285064

Butler, W. H., and B. E. Goldstein. 2010. The US fire learning network: springing a rigidity trap through multiscalar collaborative networks. Ecology and Society 15(3):21. http://dx. doi.org/10.5751/ES-03437-150321

Carpenter, S. R., and W. A. Brock. 2008. Adaptive capacity and traps. Ecology and Society 13(2):40. http://dx.doi.org/10.5751/ es-02716-130240

Carter, M. R., and C. B. Barrett. 2006. The economics of poverty traps and persistent poverty: an asset-based approach. Journal of Development Studies 42:178-199. http://dx.doi.org/10.1080/0022$\underline{0380500405261}$
Carter, T. 2009. Developing conservation subdivisions: ecological constraints, regulatory barriers, and market incentives. Landscape and Urban Planning 92(2):117-124. http://dx.doi.org/10.1016/j. landurbplan.2009.03.004

Cervero, R., and C. Radisch. 1996. Travel choices in pedestrian versus automobile oriented neighborhoods. Transportation Policy 3:127-141. http://dx.doi.org/10.1016/0967-070X(96)00016-9

Chaffin, B. C., A. S. Garmestani, L. H. Gunderson, M. H. Benson, D. G. Angeler, C. A. (T.) Arnold, B. Cosens, R. K. Craig, J. B. Ruhl, and C. R. Allen. 2016. Transformative environmental governance. Annual Review of Environment and Resources 41:399-423. http://dx.doi.org/10.1146/annurev-environ-110615-085817

Choi, C. 2009. Removing market barriers to green development: principles and action projects to promote widespread adoption of green development practices. Journal of Sustainable Real Estate 1(1):107-138.

Choi, E., and N. Miller. 2011. Explaining LEED concentration: effects of public policy and political party. Journal of Sustainable Real Estate 3(1):91-108.

Church, M. S. 2014. Neighborhood health: a new framework for investing in sustainable communities. Community Development Investment Review, Federal Reserve Bank of San Francisco, California, USA. [online] URL: http://www.frbsf.org/communitydevelopment/files/cdir vol10issue1-Neighborhood-Health.pdf

Cinner, J. E. 2011. Social-ecological traps in reef fisheries. Global Environmental Change 21(3):835-839. http://dx.doi.org/10.1016/ j.gloenvcha.2011.04.012

Coiacetto, E. 2006. Real estate development industry structure: consequences for urban planning and development. Planning Practice and Research 21(4):423-441. http://dx.doi. org/10.1080/02697450601173355

Coiacetto, E. 2007. The role of the development industry in shaping urban social space: a conceptual model. Geographical Research 45(4):340-347. http://dx.doi.org/10.1111/j.1745-5871.2007.00473. $\underline{\mathrm{X}}$

Colding, J. 2007. 'Ecological land-use complementation' for building resilience in urban ecosystems. Landscape and Urban Planning 81(1-2):46-55. http://dx.doi.org/10.1016/j. landurbplan.2006.10.016

Congress for the New Urbanism (CNU). 2016. Our projects. Congress of the New Urbanism, Washington, D.C., USA. [online] URL: https://www.cnu.org/what-we-do/our-projects

Cook, E. M., S. J. Hall, and K. L. Larson. 2012. Residential landscapes as social-ecological systems: a synthesis of multiscalar interactions between people and their home environment. Urban Ecosystems 15:19-52. http://dx.doi.org/10.1007/s11252-011-0197-0

Coss, J. G., and M. J. Guyer. 1980. Social traps. University of Michigan Press, Ann Arbor, Michigan, USA.

Costanza, R. 1987. Social traps and environmental policy. BioScience 37(6):407-412. http://dx.doi.org/10.2307/1310564

Cowan, E. 2012. Sustainability for suburbs. Journal of Sustainable Real Estate 4(1):212-241. 
Dasgupta, P. 1997. Nutritional status, the capacity for work, and poverty traps. Journal of Econometrics 77:5-37. http://dx.doi. org/10.1016/S0304-4076(96)01804-0

Díaz, S., S. Lavorel, F. de Bello, F. Quétier, K. Grigulis, and T. M. Robson. 2007. Incorporating plant functional diversity effects in ecosystem service assessments. Proceedings of the National Academy of Sciences 104(52):20684-20689. http://dx.doi. org/10.1073/pnas.0704716104

Díaz, S., F. Quétier, D. M. Cáceres, S. F. Trainor, N. PérezHarguindeguy, M. S. Bret-Harte, B. Finegan, M. Peña-Claros, and L. Poorter. 2011. Linking functional diversity and social actor strategies in a framework for interdisciplinary analysis of nature's benefits to society. Proceedings of the National Academy of Sciences 108(3):895-902. http://dx.doi.org/10.1073/pnas.1017993108

Duany, A. 2013. 20 years of new urbanism. Pages 9-14 in E. Talen, editor. Charter of new urbanism. Second edition. McGraw-Hill, New York, New York, USA.

Duany, A., E. Plater-Zyberk, and J. Speck. 2001. Suburban nation: the rise of sprawl and the decline of the American dream. North Point Press, New York, New York, USA.

Duany, A., and E. Talen, E. 2002. Transect planning. Journal of the American Planning Association 68(3):245-266. http://dx.doi. org/10.1080/01944360208976271

Duncan, M. 2011. The impact of transit-oriented development on housing prices in San Diego, CA. Urban Studies 48(1):101-127. http://dx.doi.org/10.1177/0042098009359958

Eakin, H. C., M. C. Lemos, and D. R. Nelson. 2014. Differentiating capacities as a means to sustainable climate change adaptation. Global Environmental Change 27:1-8. http:// dx.doi.org/10.1016/j.gloenvcha.2014.04.013

Eichholtz, P., N. Kok, and J. M. Quigley. 2010. Doing well by doing good? Green office buildings. American Economic Review 100(5):2492-2509. http://dx.doi.org/10.1257/aer.100.5.2492

Ellis, C. 2002. The new urbanism: critiques and rebuttals. Journal of Urban Design 7(3):261-291. http://dx.doi.org/10.1080/135748$\underline{0022000039330}$

Enqvist, J., M. Tengö, and W. J. Boonstra. 2016. Against the current: rewiring rigidity trap dynamics in urban water governance through civic engagement. Sustainability Science 11 (6):919-933. http://dx.doi.org/10.1007/s11625-016-0377-1

Ernstson, H., S. E. van der Leeuw, C. L. Redman, D. J. Meffert, G. Davis, C. Alfsen, and T. Elmqvist. 2010. Urban transitions: on urban resilience and human-dominated ecosystems. Ambio 39 (8):531-545. http://dx.doi.org/10.1007/s13280-010-0081-9

Ewing, R. 1994. Characteristics, causes, and effects of sprawl: a literature review. Environmental and Urban Studies 21(2):1-15.

Ewing, R., T. Schmid, R. Killingsworth, A. Zlot, and S. Raudenbush. 2008. Relationship between urban sprawl and physical activity, obesity, and morbidity. Pages 567-582 in J. M. Marzluff, E. Shulenberger, W. Endlicher, M. Alberti, G. Bradley, C. Ryan, U. Simon, and C. ZumBrunnen, editors. Urban ecology. Springer-Verlag, New York, New York, USA. http://dx.doi. org/10.1007/978-0-387-73412-5 37
Falkenbach, H., A. Lindholm, and H. Schleich. 2010. Environmental sustainability: drivers for the real estate investor. Journal of Real Estate Literature 18(2):203-223.

Farr, D. 2008. Sustainable urbanism: urban design with nature. Wiley, New York, New York, USA.

Fuerst, F., and P. M. McAllister. 2009. An investigation of the effect of eco-labeling on office occupancy rates. Journal of Sustainable Real Estate 1(1):49-64.

Galuppo, L., and C. Tu. 2010. Capital markets and sustainable real estate: What are the perceived risks and barriers? Journal of Sustainable Real Estate 2(1):143-159.

Garde, A. 2009. Sustainable by design?: Insights from U.S. LEEDND pilot projects. Journal of the American Planning Association 75(4):424-440. http://dx.doi.org/10.1080/01944360903148174

Geoghegan, J. 2002. The value of open spaces in residential land use. Land Use Policy 19(1):91-98. http://dx.doi.org/10.1016/ $\underline{\mathrm{s} 0264-8377(01) 00040-0}$

Göçmen, Z. A. 2013. Barriers to successful implementation of conservation subdivision design: a closer look at land use regulations and subdivisions permitting process. Landscape and Urban Planning 110:123-133. http://dx.doi.org/10.1016/j. landurbplan.2012.11.002

Goering, J. 2009. Sustainable real estate development: the dynamics of market penetration. Journal of Sustainable Real Estate 1(1):167-201.

Grant, J. L. 2009. Theory and practice in planning the suburbs: challenges to implementing new urbanism, smart growth, and sustainability principles. Planning Theory \& Practice 10(1):11-33. http://dx.doi.org/10.1080/14649350802661683

Green, O. O., A. S. Garmestani, S. Albro, N. C. Ban, A. Berland, C. E. Burkman, M. M. Gardiner, L. Gunderson, M. E. Hopton, M. L. Schoon, and W. D. Schuster. 2016. Adaptive governance to promote ecosystem services in urban green space. Urban Ecosystems 19:77-93. http://dx.doi.org/10.1007/s11252-015-0476-2

Grimm, N. B., S. H. Faeth, N. E. Golubiewski, C. L. Redman, J. Wu, X. Bai, and J. M. Briggs. 2008. Global change and the ecology of cities. Science 319(5864):756-760. http://dx.doi.org/10.1126/ $\underline{\text { science. } 1150195}$

Groffman, P. M., J. Cavender-Bares, N. D. Bettez, J. M. Grove, S. J. Hall, J. B. Heffernan, S. E. Hobbie, K. L. Larson, J. L. Morse, C. Neill, K. Nelson, J. O'Neil-Dunne, L. Ogden, D. E. Pataki, C. Polsky, R. R. Chowdhury, and M. K. Steele. 2014. Ecological homogenization of urban USA. Frontiers in Ecology and the Environment 12(1):74-81. http://dx.doi.org/10.1890/120374

Gunderson, L., and C. S. Holling. 2002. Panarchy: understanding transformations in human and natural systems. Island Press, Washington, D.C., USA.

Gyourko, J. E., and W. Rybczynski. 2000. Financing new urbanism projects: obstacles and solutions. Housing Policy Debate 11(3):733-750. http://dx.doi.org/10.1080/10511482.2000.9521384

Hackworth, J. 2007. The neoliberal city: governance, ideology, and development in American urbanism. Cornell University Press, Ithaca, New York, USA. 
Hayden, D. 2003. Building suburbia: green fields and urban growth: 1820-2000. Pantheon Books, New York, New York, USA.

Hayden, D. 2004. A field guide to sprawl. W.W. Norton and Company, New York, New York, USA.

Heid, J. 2004. Greenfield development without sprawl: the role of planned communities. Urban Land Institute, Washington, D.C., USA.

Hess, D. B., and T. M. Almeida. 2007. Impact of proximity to light rail rapid transit on station-area property values in Buffalo, New York. Urban Studies 44(5-6):1041-1068. http://dx.doi. org/10.1080/00420980701256005

Higgins, T. 2015. Water quality is not only a big issue for big lakes. Ohio Ag Net: Ohio's Country Journal, 12 March. [online] URL: http://ocj.com/2015/03/water-quality-is-not-only-a-big-issue-forbig-lakes/

Hostetler, M., and D. Drake. 2009. Conservation subdivisions: a wildlife perspective. Landscape and Urban Planning 90 (3-4):95-101. http://dx.doi.org/10.1016/j.landurbplan.2008.10.018

Hurley, P. T. 2012. Whose sense of place?: a political ecology of amenity development. Pages 165-180 in W. P. Stewart, D. R. Williams, and L. E. Kruger, editors. Place-based conservation: perspectives from the social sciences. Springer, New York, New York, USA. http://dx.doi.org/10.1007/978-94-007-5802-5_13

Jabareen, Y. R. 2006. Sustainable urban forms: their typologies, models, and concepts. Journal of Planning Education and Research 26:38-52. http://dx.doi.org/10.1177/0739456X05285119

Jackson, K. T. 1985. Crabgrass frontier: the suburbanization of the United States. Oxford University Press, Oxford, UK.

Kaza, N. and T. K. BenDor. 2013. The land value impacts of wetland restoration. Journal of Environmental Management 127:289-299. http://dx.doi.org/10.1016/j.jenvman.2013.04.047

Kingsley, B. S. 2008. Making it easy to be green: using impact fees to encourage green building. New York University Law Review 83 (2).

Kok, N., M. McGraw, and J. M. Quigley. 2012. The diffusion over time and space of energy efficiency in building. Annals of Regional Science 48(2):541-564. http://dx.doi.org/10.1007/s00168-011-0494-9

Kopits, E., V. McConnell, and M. Walls. 2007. The trade-off between private lots and public open space in subdivisions at the urban-rural fringe. American Journal of Agricultural Economics 89:1191-1197.

Krause, A. L., and C. Bitter. 2012. Spatial econometrics, land values and sustainability: trends in real estate valuation research. Cities 29:S19-S25. http://dx.doi.org/10.1016/j.cities.2012.06.006

Langlois, P. 2010. Municipal visions, market realities: does planning guide residential development? Environment and Planning B: Urban Analytics and City Science 37:449-462. http:// dx.doi.org/10.1068/b34103

Leichenko, R. M., and W. D. Solecki. 2005. Exporting the American dream: the globalization of suburban consumption landscapes. Regional Studies 39(2):241-253. http://dx.doi. org $/ 10.1080 / 003434005200060080$
Leinberger, C. B. 2001. Financing progressive development. The Brookings Institution Center on Urban and Metropolitan Policy and Harvard University Joint Center for Housing Studies, Cambridge, Massachusetts, USA. [online] URL: http://www. brookings.edu/ /media/research/files/articles/2001/5/metropolitanpolicyleinberger/leinberger.pdf

Lutzenhiser, M., and N. R. Netusil. 2001. The effect of open spaces on a home's sale price. Contemporary Economic Policy 19 (3):291-298. http://dx.doi.org/10.1093/cep/19.3.291

Markus, M., and F. Savini. 2016. The implementation deficits of adaptation and mitigation: green buildings and water security in Amsterdam and Boston. Planning Theory and Practice 17 (4):497-515. http://dx.doi.org/10.1080/14649357.2016.1210666

Meerow, S., and J. P. Newell. 2016. Urban resilience for whom, what, when, where, and why? Urban Geography 1-21. http://dx. doi.org/10.1080/02723638.2016.1206395

Meerow, S., J. P. Newell, and M. Stults. 2016. Defining urban resilience: a review. Landscape and Urban Planning 147:38-49. http://dx.doi.org/10.1016/j.landurbplan.2015.11.011

Miller, N., J. Spivey, and A. Florance. 2008. Does green pay off? Journal of Real Estate Portfolio Management 14(4):385-399.

Mohamed, R. 2006. The psychology of residential developers: lessons from behavioral economics and additional explanations for satisficing. Journal of Planning Education and Research 26:28-37. http://dx.doi.org/10.1177/0739456X05282352

Mohamed, R. 2009. Why do residential developers prefer large exurban lots? Infrastructure costs and exurban development. Environment and Planning B: Urban Analytics and City Science 36:12-29. http://dx.doi.org/10.1068/b33120

Moore, M. L., and F. Westley. 2011. Surmountable chasms: networks and social innovation for resilient systems. Ecology and Society 16(1):5. http://dx.doi.org/10.5751/es-03812-160105

Oleyar, M. D., A. I. Greve, J. C. Withey and A. M. Bjorn. 2008. An integrated approach to evaluating urban forest functionality. Urban Ecosystems 11:289-308. http://dx.doi.org/10.1007/ $\underline{\mathrm{s} 11252-008-0068-5}$

Ostrom, E. 2010. Polycentric systems for coping with collective action and global environmental change. Global Environmental Change 20(4):550-557. http://dx.doi.org/10.1016/j.gloenvcha.2010.07.004

Pejchar, L., P. M. Morgan, M. R. Caldwell, C. Palmer, and G. C. Daily. 2007. Evaluating the potential for conservation development: biophysical, economic, and institutional perspectives. Conservation Biology 21:69-78. http://dx.doi.org/10.1111/ j.1523-1739.2006.00572.x

Pincetl, S. 2010. From the sanitary city to the sustainable city: challenges to institionalising biogenic (nature's services) infrastructure. Local Environment 15(1):43-58. http://dx.doi. org/10.1080/13549830903406065

Pinedo, A. T., B. D. Hirshberg, T. A. Humphreys, and D. J. Goett. 2016. Frequently asked questions about real estate investment trusts. Morrison and Forester LLP, San Francisco, California, USA. [online] URL: http://media.mofo.com/files/Uploads/ Images/FAQ REIT.pdf 
Polsky, C., J. M. Grove, C. Knudson, P. M. Groffman, N. Bettez, J. Cavender-Bares, S. J. Hall, J. B. Heffernan, S. E. Hobbie, K. L. Laron, J. L. Morse, C. Neill, K. C. Nelson, L. A. Ogden, J. O' Neil-Dunne, D. E. Pataki, R. R. Chowdhury, and M. K. Steele. 2014. Assessing the homogenization of urban land management with an application to US residential lawn care. Proceedings of the National Academy of Sciences 111(12):4432-4437. http://dx. doi.org/10.1073/pnas.1323995111

Retzlaff, R. C. 2008. Green building assessment systems: a framework and comparison for planners. Journal of the American Planning Association 74(4):505-519. http://dx.doi. org/10.1080/01944360802380290

Rohde, C., and T. Lutzkendorf. 2009. Step-by-step to sustainable property investment products. Journal of Sustainable Real Estate 1(1):227-240.

Rudel, T. K., K. O'Neil, P. Gottlieb, M. McDermott, and C. Hatfield. 2011. From middle to upper class sprawl? Land use controls and changing patterns of real estate development in northern New Jersey. Annals of the Association of American Geographers 101(3):609-624. http://dx.doi.org/10.1080/0004560$\underline{8.2011 .560062}$

Runde, T. P., and S. Thoyre. 2010. Integrating sustainability and green building into the appraisal process. Journal of Sustainable Real Estate 2(1):221-248.

Rybczynski, W. 2007. Last harvest: from cornfield to new town. Scribner, New York, New York, USA.

Scheffer, M., and F. R. Westley. 2007. The evolutionary basis of rigidity: locks in cells, minds, and society. Ecology and Society 12 (2):36. http://dx.doi.org/10.5751/es-02275-120236

Seto, K. C., R. Sánchez-Rodríguez, and M. Fragkias. 2010. The new geography of contemporary urbanization and the environment. Annual Review of Environment and Resources 35:167-194. http://dx.doi.org/10.1146/annurev-environ-100809-125336

Sharpe, J. 2011. Pushing boundaries in Arizona. Urban land: the Magazine of the Urban Land Institute, 26 April. [online] URL: http://urbanland.uli.org/economy-markets-trends/pushing-boundariesin-arizonal

Shearer, H., P. Taygfeld, E. Coiacetto, J. Dodson, and Z. Banhalmi-Zakar. 2013. The role and capabilities of private sector developers and financing in urban climate change adaptation: the South East Queensland case. Final Report to the National Climate Change Adaptation Research Facility, Gold Coast, Australia. [online] URL: https://www.nccarf.edu.au/sites/default/files/ attached files publications/Shearer 2013 Capacities of private developers.pdf

Simatupang, T. M., and R. Sridharan. 2002. The collaborative supply chain. International Journal of Logistics Management 13 (1):15-30. http://dx.doi.org/10.1108/09574090210806333

Song, Y., and G.-J. Knaap. 2004. Measuring the effects of mixed land uses on housing values. Regional Science and Urban Economics 34:663-680. http://dx.doi.org/10.1016/j. regsciurbeco.2004.02.003

Steneck, R. S., T. P. Hughes, J. E. Cinner, W. N. Adger, S. N. Arnold, F. Berkes, S. A. Boudreau, K. Brown, C. Folke, L.
Gunderson, P. Olsson, M. Scheffer, E. Stephenson, B. Walker, J. Wilson, and B. Worm. 2011. Creation of a gilded trap by the high economic value of the Maine lobster fishery. Conservation Biology 25(5):904-912. http://dx.doi.org/10.1111/j.1523-1739.2011.01717. $\underline{x}$

Talen, E. 2010. Affordability in new urbanist development: principle, practice, and strategy. Journal of Urban Affairs 32 (4):489-510. http://dx.doi.org/10.1111/j.1467-9906.2010.00518.x

Talen, E. 2013. Prospects for walkable, mixed-income neighborhoods: insights from U.S. developers. Journal of Housing and the Built Environment 28:79-94. http://dx.doi.org/10.1007/ $\underline{\text { s10901-012-9290-9 }}$

Talen, E., and C. Ellis. 2002. Beyond relativism: reclaiming the search for good city form. Journal of Planning Education and Research 22:36-49. http://dx.doi.org/10.1177/0739456X0202200104

The Town Paper. 2016. TND Neighborhoods by state and county. The Town Paper, Gaithersburg, Maryland, USA. [online] URL: http://www.tndtownpaper.com/neighborhoods.htm

Tilt, J. H., and L. Cerveny. 2013. Master-planned in exurbia: examining the drivers and impacts of master-planned communities at the urban fringe. Landscape and Urban Planning 114:102-112. http://dx.doi.org/10.1016/j.landurbplan.2013.03.003

Trudeau, D., and P. Malloy. 2011. Suburbs in disguise? Examining the geographies of the new urbanism. Urban Geography 32 (3):424-447. http://dx.doi.org/10.2747/0272-3638.32.3.424

Turner, V. K. 2014. Institutional barriers to sustainable urban development: a case study of Civano in Tucson, Arizona. Cities and the Environment 7(2):5.

Turner, V. K. 2016. How do conventional master planning processes facilitate or constrain sustainable urbanism? An environmental management perspective. Society \& Natural Resources 29(12):1483-1500. http://dx.doi.org/10.1080/08941920.2016 .1150539

Turner, V. K., and C. S. Galletti. 2015. Do sustainable urban designs generate more ecosystem services? A case study of Civano in Tucson, Arizona. Professional Geographer 67(2):204-217. http://dx.doi.org/10.1080/00330124.2014.922021

Tzoulas, K., K. Korpela, S. Venn, V. Yli-Pelkonen, A. Kaźmierczak, J. Niemela, and P. James. 2007. Promoting ecosystem and human health in urban areas using green infrastructure: a literature review. Landscape and Urban Planning 81(3):167-178. http://dx.doi.org/10.1016/j.landurbplan.2007.02.001

U.S. Department of Housing and Urban Development. 2016. New residential construction. U.S. Department of Housing and Urban Development, Washington, D.C., USA. [online] URL: http://www.census.gov/construction/nrc/index.html

U.S. Green Building Council (US GBC). 2016a. Leadership in energy efficiency and design for neighborhood development projects. USGBC, Washington, D.C., USA.

U.S. Green Building Council (US GBC). 2016b. Leadership in energy efficiency and design projects. USGBC, Washington, D.C., USA. 
Valderrama, A. 2016. Pay for performance meets green infrastructure. National Resource Defense Council, New York, New York, USA. [online] URL: https://www.nrdc.org/experts/ alisa-valderrama/pay-performance-meets-green-infrastructure

Vrijhoef, R. 2011. Supply chain integration in the building industry: the emergence of integrated and repetitive strategies in a fragmented and project-driven industry. Dissertation. Delft University of Technology, Delft, The Netherlands. [online] URL: http:// repository.tudelft.nl/islandora/object/uuid:bc30b618-9b1b-4389$\underline{-8 \mathrm{a} 19-8 \mathrm{a} 3 \mathrm{ece} 1 \mathrm{fea} 62 \text { ?collection=research }}$

Wald, D. M., and M. E. Hostetler. 2010. Conservation value of residential open space: designation and management language of Florida's land development regulations. Sustainability 2:1536-1552. http://dx.doi.org/10.3390/su2061536

Weiss, M. 1987. The rise of the community builders: the American real estate industry and urban land planning. Columbia University Press, New York, New York, USA.

White, R. J. III. 2014. Application of social impact bonds in built infrastructure sustainability projects. Dissertation. Texas A\&M University, College Station, Texas, USA. [online] URL: http:// oaktrust.library.tamu.edu/bitstream/handle/1969.1/152577/WHITEDISSERTATION-2014.pdf? sequence $=1$

Wiley, J. A., J. D. Benefield, and K. H. Johnson. 2010. Green design and the market for commercial office space. Journal of Real Estate Finance and Economics 41:228-243. http://dx.doi. org/10.1007/s11146-008-9142-2

Wise, S. 2008. Green infrastructure rising. Planning 74(14):19.

Youngentob, K., and M. E. Hostetler. 2005. Is a new urban development model building greener communities? Environment and Behavior 37(6):731-759. http://dx.doi.org/10.1177/0013916505275311

Zimmerman, J. 2001. The "nature" of urbanism on the new urbanist frontier: sustainable development, or defense of the suburban dream? Urban Geography 22(3):249-267. http://dx.doi. org/10.2747/0272-3638.22.3.249 